DOI: 10.14451/2.148.33

\title{
ПРАКТИЧЕСКИЕ АСПЕКТЫ ФИНАНСОВО-ЭКОНОМИЧЕСКОЙ ЭКСПЕРТИЗЫ УСТАНОВЛЕНИЯ ТАРИФОВ НА ОБСЛУЖИВАНИЕ ИМУЩЕСТВА ОБЩЕГО ПОЛЬЗОВАНИЯ В КОТТЕДЖНЫХ ПОСЕЛКАХ
}

\author{
(c) 2020 Князева Наталья Владимировна \\ доктор экономических наук, кандидат юридических наук, аудитор, лингвист \\ Генеральный директор Ассоциации профессиональной судебной экспертизы, Россия, Москва \\ E-mail: kniazeva@expertforensic.ru \\ (c) 2020 Павлова Ксения Сергеевна \\ кандидат экономических наук, доцент \\ Самарский государственный экономический университет, Россия, Самара \\ E-mail: mrs.pavlova@list.ru
}

\begin{abstract}
В статье представлена избранная судебная практика по вопросу установления и индексации тарифов на содержание имущества общего пользования коттеджного поселка. Выделена проблема отсутствия законодательных требований, регламентирующих данный вид деятельности. По мнению авторов, введение в законодательство требования обязательного лицензирования деятельности управления коттеджным поселком и соответственно установление требований к уровню квалификации сотрудников управляющей компании, осуществляющей данную деятельность, может значительно повысить качество оказываемых услуг. Другой актуальной проблемой в настоящее время является отсутствие законодательно установленной обязанности публиковать отчётную и иную информацию о деятельности такой управляющей компании. В статье высказывается экспертное мнение о необходимости обеспечения свободного доступа к информации, что позволит обеспечить прозрачность контроля финансовых ресурсов собственников недвижимого имущества, а также анализировать эффективность деятельности управляющей компании. Представлена модель проведения процессуальной (судебной) экспертизы, применяемых управляющей компанией тарифов на основе сопоставления данных бухгалтерского учета о произведенных расходах по конкретному объекту управления и утвержденных общим собранием собственников смет на содержание имущества общего пользования коттеджного поселка.
\end{abstract}

Ключевые слова: правовое регулирование сферы ЖКХ, управляющая компания, тарифы ЖКХ, эксплуатационные компании, имущество общего пользования, коттеджный поселок, упрощенная система налогообложения, бухгалтерский учет, раздельный учет, общее собрание собственников, многоквартирный дом, товарищество собственников жилья, ТСЖ, ТСН.

При использовании в речевой конструкции как письменной, так и устной термина «коттеджный поселок», который не имеет на момент написания настоящей статьи законодательного определения, субъект, воспринимающий текст, представит себе некую обособленную, чаще охраняемую, зону малоэтажной индивидуальной жилой застройки, состоящую из скопления малоэтажных жилых домов, административных построек и элементов инфраструктуры.

Обычно коттеджный поселок не является отдельным поселением, но имеет собственное название и адрес, соответствующий регистрации созданного товарищества собственников жилья (ТСЖ), товарищества собственников недвижимости (ТСН) или адресу имущества общего поль- зования. Фактические границы коттеджного поселка могут соответствовать зоне, определенной застройщиком при планировании данного поселка, или проходит по границе участков собственников, объединившихся в ТСЖ (ТСН).

В специальной строительной нормативной терминологии существует понятие зона коттеджной застройки, под которым подразумеваются территории, на которых размещаются отдельно стоящие одноквартирные 1-2-3-этажные жилые дома с участками, как правило, от 800 до 1200 м2 и более, как правило, не предназначенными для осуществления активной сельскохозяйственной деятельности существующие на период производства исследования границы [21]. По факту данные размеры могут иметь 
иные размеры, однако характеристики этажности объектов недвижимости, расположенных на смежных земельных участках коттеджного поселка, соответствуют объектам индивидуального жилищного строительства, дому блокированной застройки.

В каждом коттеджном поселке существует территория общего пользования, прилегающая к земельным участкам, находящимся в частной собственности владельцев жилых домов. Территория общего пользования обязательно прилегает к зданию, строению, сооружению, земельному участку в случае, если такой земельный участок образован, и границы данной территории определены правилами благоустройства территории муниципального образования в соответствии с порядком, установленным законом субъекта Российской Федерации с присвоением кадастрового номера и имеет иные характеристики. Для обслуживания потребностей жителей поселка, обеспечения нормальной жизнедеятельности, при строительстве коттеджного поселка встраивается инженерная инфраструктура.

Чтобы выяснить состав имущества общего пользования коттеджного посёлка необходимо обратиться к проекту планировки и межевания, в котором указаны контрольные пункты, улицы, тротуары, ограждения и другие элементы. В проектной документации на инженерные коммуникации содержится информация о сетевых коммуникациях, подающих газ, электричество, обеспечивающих водоснабжение и отток канализации, а также узлы технологического присоединения и можно ли к ним подключиться дополнительным участникам в будущем.

Территория общего пользования нуждается в благоустройстве, то есть проведении комплекса мероприятий, установленного правилами благоустройства; инфраструктура поселка требует в свою очередь содержания. Собственники коттеджей, расположенных в границах поселков имеют право создать товарищество собственников жилья, исходя из норм, закреплённых в п.2 ч.2 ст. 136 Жилищного кодекса Российской Федерации (далее ЖК РФ). При этом отметим, что при буквальном прочтении указанной законодательной нормы для принятия решения о создании товарищества должны участвовать собственники жилых домов, расположенных близко, имеющих общую границу, в пределах которых расположены сети инженерно-технического обеспечения, другие элементы инфраструктуры, которые предназначены для обслуживания более чем одного жилого дома.

Важно отметить, что в соответствии с нормами ЖК РФ принятие решения о создании ТСЖ, а также об утверждении его устава принимаются по соглашению всех собственников данных домов. Данная юридическая норма приводится нами, с целью подчеркнуть важность участия каждого отдельного собственника для создания ТСЖ или ТСН. При нежелании или простом неучастии одного собственника недвижимости, расположенной в границах коттеджного поселка, очевидно, что ТСЖ создать затруднительно. По мнению практиков, большая часть таких ТСЖ создана с существенными нарушениями, так как невыполнимо условия стопроцентного участия и согласия владельцев жилой недвижимости, расположенной в зоне коттеджного поселка [19].

И территория, и инфраструктура являются имуществом общего пользования, при этом право долевой собственности на данное имущество у владельцев коттеджей не возникает автоматически, как, например, это происходит в многоквартирном доме. Дело об определении права собственности на имущество общего пользования коттеджных поселков дошло в правосудии до Конституционного Суда РФ, который в Постановлении № 23-П от 11.10.2016 г. указал, что закон непосредственно не связывает сам по себе факт приобретения права собственности на индивидуальный жилой дом с возникновением доли в праве собственности на имущество общего пользования [10].

Зависимость бремени содержания имущества общего пользования от наличия права собственности на него породили ряд споров, перешедших в судебную плоскость, вытекающих из несогласия собственников коттеджных поселков содержать имущество, которое фактически им не принадлежит. Однако Конституционный Суд РФ в Определении от 25.06.2019 N 1625-О поставил точку в рассуждениях подобного рода [4]. Приведем коротко суть дела.

Гражданин РФ подал в Конституционный Суд РФ жалобу, в которой указал, что положения ч. 2 ст. 154 ЖК РФ, ч. 3 ст. 30 ЖК РФ, ст. 210 ГК РФ, п. 1 ст. 421 ГК РФ противоречат статьям 19 (часть 1), 34 (часть 2), 35 (часть 2) и 40 (часть 2) Конституции Российской Федерации, поскольку по смыслу, придаваемому им правоприменительной практикой, они возлагают на собственников жилых домов в коттеджном поселке обязан- 
ность по содержанию общего имущества, право собственности на которое зарегистрировано за иным лицом, освобождая титульного собственника указанного имущества от расходов на его содержание.

Конституционный Суд РФ отказал в принятии жалобы гражданина и указал, что представленными материалами не подтверждается применение в деле с участием заявителя части 2 статьи 154 Жилищного кодекса Российской Федерации, определяющей правила установления платы за жилое помещение и коммунальные услуги для собственника помещения в многоквартирном доме. Одновременно Судом указано, что конструкция законодательства, сосредоточенная в анализируемых нормах законодательства в части 3 статьи 30 ЖК РФ, в статье 210 ГК РФ направлены на обеспечение сохранности имущества, отвечают интересам собственников данного имущества и сами по себе не могут расцениваться как нарушающие конституционные права заявителя, указанные в жалобе.

Относительно оценки п.1 ст. 421 ГК РФ Конституционный Суд Российской Федерации указал на позицию, изложенную в Постановлении от 23 февраля 1999 года N 4-П, и указал, что отраженный в п.1 ст. 421 ГК РФ принцип свободы договора относится к основным началам гражданского законодательства. Указанная норма в ст. 421 ГК РФ направлена на обеспечение свободы договора и баланса интересов его сторон (определения Конституционного Суда Российской Федерации от 27 октября 2015 года N 2461О, от 29 сентября 2016 года N 1875-О и др.). Следовательно, данное законоположение вопреки утверждению заявителя, также не может расцениваться как нарушающее его конституционные права, перечисленные в жалобе.

Имущество общего пользования зачастую остается в собственности у застройщика, а управление ею передается специальной компанией. При этом расходы на содержание должны нести все пользователи данным имуществом.

Итак, если понимание о правах собственности на имущество общего пользования достигнуто, далее необходимо выработать позицию о его содержании и распределении бремени на фактических пользователей. При наличии зарегистрированного в установленном порядке ТСЖ (TCH) на территории коттеджного поселка порядок заключения договоров с сервисными компаниями от имени собственником, посредством созданного ТСЖ, осуществляется по правилам гражданского законодательства. При строительстве коттеджного поселка посредством одного застройщика собственники зачастую получают «в наследство» от застройщика управляющую компанию, которая осуществляет обслуживание имущества общего пользования, право на которое принадлежит застройщику, но фактическое использование и эксплуатацию осуществляют владельцы жилах домов в границах построенного малоэтажного района.

Тарифы, по которым управляющая компания оказывает услуги, и являются нашим целевым объектом, который требует подробного исследования в рамках темы статьи и предмета финансово-экономического экспертного анализа. Рассмотрим сложившуюся практику. Авторы настоящей статьи имеют представление из собственного практического экспертного опыта о сложившейся практике установления тарифов в процессе управления загородной жилой недвижимостью или коттеджными посёлкам, находящимися в границах городов и иных населенных пунктов.

Во-первых, следует отметить, что еще категория судебных разбирательств между собственниками жилых домов и управляющими компаниями ведется как по вопросам легитимности присутствия управляющей компании в качестве лица, оказывающего услуги по обслуживанию имущества общего пользования, по поводу установления управляющими компаниями тарифов, а также относительно взыскания сумм неосновательного обогащения с собственников коттеджей, которые не оплачивают услуги содержания инфраструктуры и благоустройства территории.

Если в вопросе определения собственника имущества общего пользования судебная практика при выработанной позиции Конституционного Суда РФ остановилась на несовпадении обстоятельств возникновения права на указанное имущества с практикой долевой собственности на общее имущество в многоквартирных домах, то в вопросах содержания суды применяют аналогию закона с некоторыми особенностями.

Во-первых, суды не игнорируют общее собрание собственников и утвержденные на данных собраниях тарифы. Во-вторых, суды рассматривают данные вопросы с применением ЖК РФ в части правил управления и установления тарифов и их индексации. В-третьих, суды опираются на положения ГК РФ в части доказательства 
получения неосновательного обогащения.

Сложилась неоднозначная практика в вопросах, касающихся установления тарифов на содержание имущества общего пользования коттеджных поселков, и их индексации. Например, в Определении № 307-ЭС19-2677 от 05.07.2019 г. по делу № А21-463/2018 Верховный Суд РФ указал, что предусмотренное договором управления одностороннее повышение размера платы в порядке индексации тарифа, в случае наличия данного условия в утвержденном общим собранием собственников договоре управления, является законным. В аналогичном по обстоятельствам случае по делу № A21-6042/2018, завершенный Определением № 307-ЭС19-5652 от 08.08.2019 г. Верховного Судом РФ выражена противоположная позиция. Суд констатировал, что действия общества по начислению платы за содержание жилья в размере не могут быть отличными от определенного протоколом общего собрания собственников помещений, а управляющая компания не имеет права самостоятельно увеличивать размер платы даже посредством утвержденной индексации, без отдельного решения общего собрания.

В данной статье мы бы хотели привлечь внимание к двум дополнительным проблемам, которые существуют в следствие пробела в законодательстве, выраженного в отсутствии регулирования деятельности управляющих компаний, которые ведут ее в сфере управления коттеджными поселками.

Первая проблема: отсутствие законодательных требований лицензирования деятельности управляющих компаний приводит к необязательности наличия сотрудников в данных организациях, квалификация которых, должна быть подтверждена при получении лицензии на управление, как это предусмотрено в деятельности управления многоквартирным домом.

Вторая проблема: необязательность публикации отчетной информации о деятельности управляющей компании лишает собственников контроля за деятельностью и возможности получения важной финансовой информации о деятельности компании.

Учитывая позицию Верховного суда РФ, в соответствии с которой нормы закона распространяются по аналогии на управляющие компании, управляющие коттеджным поселком [20], по нашему мнению, требования законодательства, обязывающие публиковать отчетность, установ- ленные в п. 11 ст. 162 Жилищного кодекса РФ справедливо распространить и на организации, управляющие коттеджными поселками, не имеющие лицензии. При этом проблему лицензирования или иного способа регулирования необходимо поднимать и решать, как было указано выше.

В п. 1 ст. 162 ЖК РФ указано, что договор управления многоквартирным домом заключается с управляющей организацией, которой предоставлена лицензия на осуществление деятельности по управлению многоквартирными домами в соответствии с требованиями ЖК РФ. В соответствии с диспозицией закона, если иное не установлено договором управления многоквартирным домом, управляющая организация ежегодно в течение первого квартала текущего года представляет собственникам помещений в многоквартирном доме отчет о выполнении договора управления за предыдущий год, а также размещает указанный отчет в системе.

Отсутствие лицензии у организации на управление многоквартирным домом, соотносятся с требованиями главы 19 ЖК РФ и положениями Федерального закона от 4 мая 2011 года N 99-Ф3 «О лицензировании отдельных видов деятельности» с учетом особенностей, установленных ЖК РФ и в подзаконных актах. Одновременно организация процедуры лицензирования и контроль за выполнением лицензионных требований возложена Правительством РФ на уполномоченный федеральный орган, а именно на Министерство строительства и жилищнокоммунального хозяйства Российской Федерации [14].

Изучая требования пунктов 1 и 11 статьи 162 ЖК очевидно, что договор не может быть заключен при отсутствии лицензии. Исходя из системного толкования требований и с учетом сложившейся правоприменительной практики, деятельность государственного органа по лицензированию (или отсутствие таковой деятельности) не определяет необходимость публикации финансовой отёчности и иных требований, которые возлагаются на управляющую организацию коттеджным поселком, которая в свою очередь возникает из правоприменительной практики, базирующейся в настоящее время на аналогии законодательства.

По нашему мнению, иное толкование обязанностей публикации финансовой отчетности будет ущемлять права собственников общего 
имущества коттеджного поселка, установленные в ст. 24 Конституции РФ, ЖК РФ, ГК РФ, а также п.40 Правил содержания общего имущества в многоквартирном доме и правил изменения размера платы за содержание жилого помещения в случае оказания услуг и выполнения работ по управлению, по содержанию и по ремонту общего имущества в многоквартирном доме ненадлежащего качества и (или) с перерывами, превышающими установленную продолжительность, утвержденных Постановлением Правительства РФ от 13.08.2006 N 491 [12].

Таким образом, целесообразно публиковать финансовую отчетность и иную обязательную информацию одним из установленных в законодательстве способов.

В соответствии с ч. 10 ст. 161 Жилищного кодекса РФ управляющая организация должна обеспечить свободный доступ к информации об основных показателях ее финансовохозяйственной деятельности, об оказываемых услугах и о выполняемых работах по содержанию и ремонту общего имущества в многоквартирном доме, о порядке и об условиях их оказания и выполнения, об их стоимости, о ценах (тарифах) на ресурсы, необходимые для предоставления коммунальных услуг, в соответствии со стандартом раскрытия информации, утвержденным Правительством Российской Федерации.

Согласно п. 3 Стандарта раскрытия информации организациями, осуществляющими деятельность в сфере управления многоквартирными домами, утвержденного Постановлением Правительства РФ от 23.09.2010 N 731 (далее Стандарт), управляющая организация обязана раскрывать определенные виды информации и общую информацию об управляющей организации, в том числе об основных показателях финансово-хозяйственной деятельности (включая сведения о годовой бухгалтерской отчетности, бухгалтерский баланс и приложения к нему, сведения о доходах, полученных за оказание услуг по управлению многоквартирными домами (по данным раздельного учета доходов и расходов), а также:

- сведения о расходах, понесенных в связи с оказанием услуг по управлению многоквартирными домами (по данным раздельного учета доходов и расходов); перечень многоквартирных домов, управление которыми осуществляет управляющая организация, с указанием адреса и основания управления по каждому много- квартирному дому, перечень многоквартирных домов, в отношении которых договоры управления были расторгнуты в предыдущем году, с указанием адресов этих домов и оснований расторжения договоров управления;

- общую информацию о многоквартирных домах, управление которыми осуществляет управляющая организация, в том числе характеристику многоквартирного дома (включая адрес многоквартирного дома, год постройки, этажность, количество квартир, площадь жилых и нежилых помещений и помещений, входящих в состав общего имущества в многоквартирном доме, уровень благоустройства, серию и тип постройки, кадастровый номер (при его наличии), площадь земельного участка, входящего в состав общего имущества в многоквартирном доме, конструктивные и технические параметры многоквартирного дома), а также информацию о системах инженерно-технического обеспечения, входящих в состав общего имущества в многоквартирном доме;

- информацию о выполняемых работах (оказываемых услугах) по содержанию и ремонту общего имущества в многоквартирном доме и иных услугах, связанных с достижением целей управления многоквартирным домом, в том числе сведения о стоимости указанных работ (услуг) и иных услуг;

- информацию об оказываемых коммунальных услугах, в том числе сведения о поставщиках коммунальных ресурсов, установленных ценах (тарифах) на коммунальные ресурсы, нормативах потребления коммунальных услуг;

- информацию об использовании общего имущества в многоквартирном доме;

- информацию о капитальном ремонте общего имущества в многоквартирном доме; информацию о проведенных общих собраниях собственников помещений в многоквартирном доме, результатах (решениях) таких собраний;

- отчет об исполнении управляющей организацией договора управления, отчет об исполнении смет доходов и расходов товарищества, кооператива за год;

- информацию о случаях привлечения управляющей организации, должностного лица управляющей организации к административной ответственности за нарушения в сфере управления многоквартирным домом с приложением копий документов о применении мер административного воздействия, а также сведе- 
ния о мерах, принятых для устранения нарушений, повлекших применение административных санкций.

Финансирование деятельности управляющей компании осуществляется собственниками имущества, имеющими отношение к эксплуатации инфраструктуры коттеджного поселка, посредством взимания ежемесячных платежей, которые устанавливаются в виде тарифов, и общая сумма платежа каждого владельца недвижимости исчисляется пропорционально площади собственности.

Порядок тарификации и возможности их индексации касается механизма формирования цены на содержание имущества общего пользования. Проблема взыскания стоимости содержания с собственников помещений, находящихся в границах каждой зоны малоэтажной индивидуальной жилой застройки, выливается в судебное разбирательство, где суд должен выяснить конкретную стоимость, сбереженную собственником жилого дома, состоящую из денежной стоимости, потреблённых и неоплаченных услуг. Судебные перспективы подобных дел в настоящее время приходят к необходимости проведения судебной экспертизы в области экономики и финансов для определения реальности полученных услуг в натуре, необходимости их получения каждым собственником в целях проживания или пользования имуществом, находящимся в поселке, объективности установления их размера, правильности проведения расчетов управляющей организацией за спорный период и выяснением суммы долга по состоянию на определенную дату.

Управляющая организация, являющаяся коммерческой по законодательству Российской Федерации, преследует цель - ведение деятельности с определенным уровнем рентабельности. Следовательно, о банальном возмещении расходов, понесенных ею на содержание имущества общего пользования рассуждать не логично. Управляющая компания обычно имеет организационно-правовую форму общества с ограниченной ответственностью, в соответствии с ч. 1 ст. 50 ГК РФ целью такой организации является извлечение прибыли. Управляющая компания должна иметь в составе видов деятельности выполнение хозяйственно-эксплуатационных функций, связанных с санитарно-техническим содержанием многоквартирных домов, (далее по тексту МКД). Если в управлении такой орга- низации находится коттеджный поселок, то на основании сложившейся правоприменительной практики подобная деятельность в основных аспектах регулируется положениями законодательства по управлению МКД.

Правила ведения коммерческой деятельности управляющими организациями содержатся в нормах гражданского законодательства. Налоговые рамки и правила налогообложения сосредоточены в кодифицированном акте, регулирующим налоговые правоотношения. Специальные нормы, относительно деятельности управления МКД выделены в кодифицированном жилищном законодательстве и ряде подзаконных актов.

В соответствии со специальными нормами, регулирующими жилищные тарифы, размер платы за содержание жилого помещения в многоквартирном доме определяется с учетом предложений управляющей организации и устанавливается на срок не менее чем один год (п.7 ст. 156 ЖК РФ).

Анализируя системно законодательство в части правил ценообразования, мы принимаем во внимание: пункт 2 ст. 709 ГК РФ устанавливает, что «цена в договоре подряда включает компенсацию издержек подрядчика и причитающееся ему вознаграждение»; агентские отношения воспринимают правила и нормы, установленные для комиссионных отношений и договоров поручения (ст. 1011 ГК РФ), согласно ст. 1001 ГК РФ комитент обязан помимо уплаты комиссионного вознаграждения возместить комиссионеру израсходованные им на исполнение комиссионного поручения суммы; статья 1023 ГК РФ предусматривает, что «доверительный управляющий имеет право на вознаграждение, предусмотренное договором доверительного управления имуществом, а также на возмещение необходимых расходов, произведенных им при доверительном управлении имуществом, за счет доходов от использования этого имущества».

Исходя из законодательных норм, определяющих правила ведения деятельности, права и обязанности коммерческих организаций, а также принимая во внимание специальные нормы, регулирующие деятельность по управлению, традиционным является включение в состав цены договоров о выполнении работ и оказании услуг двух составляющих: вознаграждения и издержек (расходов).

Размер платы за содержание и ремонт жилого помещения - результат договоренности 
сторон договора управления многоквартирным домом. Управляющая организация не может в одностороннем порядке (без согласования с собственниками помещений, выражающегося в принятии решения их общим собранием) устанавливать и (или) изменять размер платы.

При установлении цены содержания и ремонта жилого помещения первичен перечень работ и услуг. Перечень услуг и работ по содержанию и ремонту общего имущества в многоквартирном доме, порядок изменения такого перечня являются существенными условиями договора управления (п. 3 ст. 162 ЖК РФ). Указанный перечень подлежит утверждению на общем собрании собственников помещений (п. 17 Правил содержания и ремонта общего имущества). Все минимально необходимые работы по обслуживанию многоквартирных домов перечислены в Правилах эксплуатации жилфонда, утвержденных Постановлением Госстроя России от 27.09.2003 № 170 [9]. Также в качестве основы при разработке перечня работ и услуг для конкретного дома можно воспользоваться Приложением 2 к Правилам проведения органом местного самоуправления открытого конкурса по отбору управляющей организации для управления многоквартирным домом, утвержденным Постановлением Правительства РФ от 06.02.2006 № 75 [13]. Действующее жилищное законодательство предполагает, что перечень услуг и работ по содержанию и ремонту общего имущества устанавливается для каждого конкретного многоквартирного дома с учетом его характеристик. Соответственно, и размер платы будет индивидуальным для каждого дома.

При анализе ценообразования эксперт может ориентироваться на научно обоснованные методики и результаты исследований. Принимая во внимание мнение авторитетных ученых, а также используя экспертные оценки, эксперт опирается на положения, что в современной практике в ЖКХ общепринятым является затратное ценообразование, в соответствии с которым тариф определяется как сумма нормативных затрат на оказание различных жилищно-коммунальных услуг и прибыли, определяемой исходя из установленной нормативной рентабельности, в расчете на один квадратный метр жилых (нежилых) помещений [2]. Соответственно цена жилищнокоммунальной услуги для получателя (потребителя) рассчитывается исходя из площади используемого жилого (нежилого) помещения в многоквартирном доме (перемножением тарифа на количество квадратных метров помещения). Считается, что затратный метод ценообразования в ЖКХ объективно является наиболее эффективным, однако требующим соответствующего экономического обоснования при определении каждой составляющей тарифа.

Очевидно, что предлагаемый собственникам помещений размер платы должен быть обоснованным и должен обеспечивать управляющей организации рентабельность. Чтобы соблюсти право потребителей на изменение размера платы за содержание и ремонт жилого помещения в случае оказания услуг и выполнения работ ненадлежащего качества, стоимость каждой услуги и работы должна быть определена отдельно. Причем такая детализация целесообразна в договоре управления (и, соответственно, в отчете управляющего перед собственниками помещений), в то время как в платежном документе, как правило, не требуется разделять плату за содержание и ремонт жилого помещения на составляющие.

Порядок проведения процессуальной (судебной) экспертизы или внепроцессуального исследования примененных управляющей компанией тарифов.

Судебная (процессуальная) экспертиза или внепроцессуальное исследование примененных управляющей компанией тарифов, проводится в следующем порядке:

1) Анализ статей затрат в бухгалтерском учете, формирующих себестоимость услуг управляющей компании.

2) Исследование первичной документации управляющей компании, подтверждающей факт несения расходов в рамках договоров с поставщиками товаров, работ и услуг.

3) Сопоставление произведенных расходов по определенному объекту управления сметам (расчетов платы ставки тарифов) на содержание коттеджного поселка (далее по тексту - Смета), проверка уровня рентабельности по данному объекту.

4) Проверка правильности выставления счетов по утверждённым тарифам, с учетом установленного уровня рентабельности.

5) Проверка расчетных операций с конкретными лицами, указанными в определении суда о назначении судебной (процессуальной) экспертизы или в договоре о производстве внепроцессуального исследования

6) Оформление результатов исследования 
в заключении эксперта по форме, отвечающей процессуальным требованиям, с формулировкой четких и однозначных выводов по поставленным судом вопросам или оформление иного итогового документа, (например, акта) по результатам внепроцессуального исследования.

Порядок бухгалтерского и налогового учета управляющая компания утверждает в учетной политике организации согласно требованиям законодательства РФ [3, 22]. Применение учетной политики компаниями ведется последовательно каждый календарный год. Допущение последовательности применения документа в организации предусмотрено в п. 5 ПБУ 1/2008. Изменения учетной политики производится по основаниям, указанным в п. 10 ПБУ1/2008 согласно ч. 6 ст. 8 Закона «402-Ф3, к ним относятся $[16,22]$ :

- изменение норм законодательства по бухгалтерскому учету;

- разработка предприятием новых способов ведения бухгалтерского учета;

- существенные нововведения в условиях хозяйствования экономического субъекта, например, изменения связанные с реорганизацией деятельности или изменения видов деятельности и т.д.

Не все компании своевременно актуализируют учетную политику с учетом законодательных изменений, что может приводить к неверному отражению данных в отчетности и иной финансовой информации. Например, в случае с управляющей компанией, это может привести к неверному включению расходов в себестоимость услуг, которые затем отразятся в отчете об исполнении смет доходов и расходов управляющей компании за год (далее по тексту - Отчет об исполнении смет).

Обновление учетной политики необходимо не только для целей бухгалтерского учета, но и для целей налогового учета [3]. Изменения в налоговом российском законодательстве происходят регулярно, также меняется правоприменительная судебная практика. В связи с этим управляющей компании, как и всем юридическим лицам, необходимо отслеживать нововведения в законодательстве о налогах и сборах и вносить коррективы в учетную политику, что позволит верно сформировать налоговую базу, правильно учесть доходы и расходы для целей налогообложения.

При расчете чистой прибыли и включении в смету (расчет платы ставки тарифов) на содержание коттеджного поселка пункта рентабельности налогоплательщик также должен учитывать специфику действующего налогового законодательства. Согласно п. 12 ст. 167, ст. 313 НК РФ [3], письмам Минфина России от 08.12.2017 г. № 03-03-06/1/81943 [6] и от 03.07.2018 г. № 0303-06/1/45756 [5], для налогоплательщиков хозяйствующих субъектов является обязательным внесение изменений в учетную политику для целей налогообложения, если данный налогоплательщик решил изменить способ (метод) учета объекта налогообложения. Отметим, что в этом случаем изменения вступают в законную силу не ранее нового налогового периода. Изменение законодательства о налогах и сборах вторая причина внесения изменений в учетную политику организации для целей налогообложения [3, 5-6].

Как показывает практика, управляющие компании чаще всего относятся к субъектам малого предпринимательства, при условии, что количество сотрудников у организаций составляет менее 100 человек (ст. 4 Федерального закона от 24.07.2007 N 209-Ф3) [23]. По показателям значений доходов управляющие компании в большинстве своем также относятся к малым предприятиям, так как их доходы от предпринимательской деятельности не превышают 800 млн. рублей в год, согласно критериям отнесения бизнеса, к субъектам малых предприятий, установленным в Постановлении Правительства РФ от 04.04.2016 N 265 [11]. Отнесение к определенной категории субъектов предпринимательства позволяют управляющим компаниям применять специальный налоговый режим - упрощенную систему налогообложения (далее - УСН) как выгодную альтернативу общему режиму.

При выборе УСН управляющей компанией должны соблюдаться ограничения, установленные ст. 346.12 НК РФ: доходы организации не должны превышать 150 млн. руб. в течении одного налогового периода; остаточная стоимость основных средств не должна быть более 150 млн. руб., численность сотрудников должна быть менее 100 человек. Выбор УСН для управляющих компаний выгоден экономически. УСН заменяет налог на прибыль, основная ставка которого составляет 20\%, на упрощенный налог при выборе объекта налогообложения «Доходы», где ставка составляет - 6\%, при выборе объекта «Доходы, уменьшенные на величину расходов» - ставка 
соответственно составляет 15\% (п. 1 ст. 346.14 НК РФ). Компании на УСН освобождаются от уплаты НДС, налога на прибыль организации, что также влияет на снижение налоговой нагрузки и на сокращение документооборота. Налог на имущество компании на УСН уплачивают только с недвижимых объектов собственности организации. При условии, что налоговая база в отношении этого имущества определяется как его кадастровая стоимость (ст. 374 НК РФ) [3]. Выбор режима налогообложения управляющая компания фиксирует в соответствующей учетной политике в целях налогообложения.

С одной стороны, возможно применение объекта налогообложения «Доходы», если шестипроцентная нагрузка на платежи собственников недвижимого имущества является для них посильной и согласованной.

С другой стороны, ввиду наличия постоянных и переменных производственных расходов у управляющей компании, объектом налогообложения могут быть выбраны доходы, уменьшенные на величину расходов, в соответствии с правом предоставленным налогоплательщикам п.2 статьи 346.14 НК РФ. Расходы, указанные в пункте 1 статьи 346.14, принимаются при условии их соответствия критериям, указанным в пункте 1 статьи 252 НК РФ.

В соответствии с п. 1 ст. 252 НК РФ расходами признаются обоснованные и документально подтвержденные затраты, понесенные налогоплательщиком. Под обоснованными расходами понимаются экономически оправданные затраты, оценка которых выражена в денежной форме. Под документально подтвержденными расходами понимаются затраты, подтвержденные документами, оформленными в соответствии с законодательством Российской Федерации, либо документами, оформленными в соответствии с обычаями делового оборота. При этом расходами признаются любые затраты при условии, что они произведены для осуществления деятельности, направленной на получение дохода.

Методы признания расходов на выполнение работ и оказание услуг учитывается согласно п. 19 ПБУ 10/99 с использованием аналогии учета услуг по содержанию и ремонту общего имущества в многоквартирном доме [15]. Учет расходов на выполнение работ и оказание услуг по содержанию и ремонту общего имущества многоквартирного дома, квалифицируемые как расходы по обычным видам деятельности согласно
ПБУ 10/99, ведется на счете 20 по статьям затрат.

Состав прямых расходов организации устанавливают в учетной политике для целей налогообложения согласно ст. 318 НК РФ. Прямые расходы на производство и реализацию продукции, работ, услуг распределяются по видам деятельности по решению организации. Например, коммунальные услуги: газ, холодное водоснабжение, водоотведение, электроснабжение; услуги по содержанию коттеджного поселка, услуги по ремонту, услуги по управлению общим имуществом, где расположены системы энергоузлов, охранные услуги и прочие услуги.

Себестоимость услуг управляющей компании включает в себя статьи затрат, которые отражаются двойной бухгалтерской записью в учете Дт 20 (26) Кт $(10,60,69,71,76)$ согласно Плана счетов бухгалтерского учета финансовохозяйственной деятельности организаций, в соответствии с наименованиями [8]:

- Счет 20 «Основное производство»;

- Счет 26 «Общехозяйственные расходы»;

- Счет 10 «Материалы»;

- Счет 60 «Расчеты с поставщиками и подрядчиками»;

- Счет 69 «Расчеты по социальному страхованию и обеспечению»;

- Счет 70 «Расчеты с персоналом по оплате труда»;

- Счет 71 «Расчеты с подотчетными лицами»;

- Счет 76 «Расчеты с разными дебиторами и кредиторами».

В конце каждого отчетного периода затраты переносятся бухгалтерской записью Дт 90 Кт 20 (26), счета затрат в деятельности по оказанию услуг в большинстве случаев остатка иметь не могут, (счет 90 «Продажи»). Экономический смысл бухгалтерской записи данного вида заключается в уменьшении доходов организации на величину расходов.

Особое внимание эксперту следует уделять составу расходов, включенных в себестоимость услуг, проверять их производственный характер и оправданность стоимости услуг. Эксперту необходимо убедиться в документальном подтверждении расходов, а именно в наличии первичной документации по сделкам за исследуемый период и договоров с поставщиками товаров, работ и услуг, если это не разовые операции.

В случае, если эксперту на разрешение поставлен вопрос о рыночной стоимости по- 
требляемых управляющей компанией услуг, (например, уборка территории сторонними организациями), то эксперт проводит соответствующее сопоставление, обосновывая выбранную среднюю рыночную цену аналогичных услуг для сравнения. Если данный вопрос о сопоставлении цен не был задан эксперту, но эксперт обратил внимание на серьезные не соответствия, то он имеет право в части привлечения внимания указать это в составе своих выводов.

У управляющей компании может быть несколько объектов учета, связанных с получением доходов от управления, одновременно по обычным и прочим видам деятельности, что предполагает ведение раздельного учета доходов и расходов. Например, кроме управления общим имуществом коттеджного поселка, управляющая организация может получать доход от сдачи в аренду имущества, не связанного с данным коттеджным поселком. Бухгалтерский (и налоговый) учет доходов будет вестись в разрезе субсчетов:

1. доходы от реализации по услугам управления коттеджным поселком по соответствующему ОКВЭД, указанному в выписке ЮГРЮЛ в виде основного вида деятельности;

2. доходы по другим видам деятельности (по дополнительным ОКВЭД);

3. доходы от внереализационной деятельности (ст.250 НК РФ) [3].

Раздельный учет доходов должен быть организован в соответствии с нормами НК РФ, а именно: ст. 248 НК РФ, для компаний, применяющих общий режим налогообложения, и ст. 346.15 НК РФ, для организаций на упрощенной системе налогообложения.

Расходы будут учитываться также в разрезе раздельного учета пропорционально как: расходы от реализации по каждому объекту учета, внереализационные и прочие расходы (ст. 274 НК РФ) [3].

Проблемным вопросом является признание общехозяйственных расходов для целей налогообложения и включение их в затраты по основному виду деятельности управляющей компании, если такие расходы невозможно распределить пропорционально по конкретному виду деятельности. В подобном случае, согласно п. 1.1 ст. 272 НК РФ при методе начисления такие расходы распределяются пропорционально доле дохода по соответствующему виду деятельности организации в суммарном объеме всех доходов пред- приятия. Так как НК РФ не установлена методика ведения раздельного учета доходов и расходов, то налогоплательщик вправе самостоятельно выбрать порядок их учета, который позволит разграничить полученные доходы и понесенные расходы по видам деятельности организации, и в частном случае управляющей компании в том числе. Данная позиция отражена в письме Минфина России от 09.02.2016 № 03-03-06/1/6641 [7]. Такой подход актуален также для компаний, применяющих кассовый метод при определении доходов и расходов, и для предприятий на УСН (см. ст 273 НК РФ и ст.346.17) [3].

При сопоставлении произведенных расходов по определенному объекту управления данным Смет, утвержденных общим собранием собственников имущества коттеджного поселка, экспертом исследуются затраты, которые были учтены в бухгалтерском учете при формировании себестоимости услуг. Некоторые управляющие компании дополнительно формируют экономические таблицы, где распределяются понесенные организацией расходы по статьям Отчета об исполнении сметы. Поэтому при проведении судебной экспертизы или внепроцессуального исследования, эксперт должен обращать внимание на принятый порядок учета расходов в организации. В случае если статьи затрат из Сметы не коррелируются с данными бухгалтерского учета или с данными экономических таблиц напрямую, эксперт должен самостоятельно сопоставить эти данные, чтобы удостовериться, что фактически понесенные расходы управляющей компании за исследуемый период соответствуют направлениям расходов, утвержденным общим собранием собственников.

Следующим этапом, является проверка уровня рентабельности управляющей компании, расчётный показатель которой может включаться в Смету. Показатель рентабельности рассчитывается экспертом, исходя из данных бухгалтерской (финансовой отчетности), как отношение прибыли управляющей компании до налогообложения и ее показателя выручки за исследуемый период, результат приводится в процентном соотношении. При расчете показателей рентабельности услуг эксперт должен учесть не только реальные расчетные показатели деятельности управляющей компании, но и уровень рентабельности, который определен для календарных периодов ФНС России [18] и является рекомендованным показателем. Дан- 
ные расчетные показатели исчислялись как средний уровень по отрасли на основании статистического наблюдения и изучения. Тем не менее данный показатель может быть уместно использован для получения мнения о прибыльности компании с точки зрения обычных среднестатистических данных. Данные показатели рассчитываются ФНС России ежегодно. Так, например, уровень рентабельности проданных товаров, продукции, работ, услуг и рентабельность активов организаций по виду экономической деятельности - деятельность по операциям с недвижимым имуществом - должна составлять 15,4\% по данным ФНС России на 2016 г [1].

При исследовании примененного управляющей компанией уровня рентабельности эксперт должен полагаться не только на данные бухгалтерского учета, но и на опубликованную бухгалтерскую финансовую отчётность, сопоставляя информацию, содержащуюся в оборотно-сальдовой ведомости и формах бухгалтерской отчетности. О необходимости публикации отчетности управляющих компаний мы упоминали выше. Состав промежуточной и годовой бухгалтерской (финансовой) отчетности зависит от размера организации [17, 22]. Промежуточную отчетность сдают организации, в чьем уставе учредители зафиксировали такую особенность. Малые компании сдают отчетность по упрощенным формам. Согласно нормам ПБУ 4/99 к годовой бухгалтерской отчетности относится:

1. бухгалтерский баланс;

2. отчет о прибылях и убытках;

3. приложения к бухгалтерскому балансу и отчету о прибылях и убытках и пояснительная записка;

4. аудиторское заключение, которое подтверждает достоверность бухгалтерской отчетности организации (этот пункт относится к организациям, которые подлежат обязательному аудиту согласно ФЗ № 307 «Об аудиторской деятельности») [24].

Управляющие компании, отнесенные к субъектам малого предпринимательства, как и другие малые предприятия имеют право представлять раз в год упрощенную бухгалтерскую (финансовую) отчетность согласно п. 4 ст. 6 Федерального закона от 06.12.2011 N 402-ФЗ. Коммерческие организации, которые применяют упрощенный способ ведения бухгалтерского учета, составляют только бухгалтерский баланс и отчет о финансовых результатах.

Основной задачей сопоставления понесенных затрат организации с направлениями расходов, утвержденным общим собранием собственников в Смете является подтверждение правильности расчета тарифа, применяемого управляющей компанией за рассматриваемый период времени. Тарифы рассчитываются на 1 кв. метр недвижимости, расположенной на территории коттеджного поселка и находящейся в собственности у определенных лиц. Установленные тарифы могут изменяться в связи с переоценкой условий оказания услуг, изменением общей площади коттеджного поселка, сменой поставщиков и подрядчиков, введением дополнительных услуг. Все изменения в Сметах должны утверждаться собственниками коттеджного поселка на общем собрании с проведением голосования по вопросам, включенных в повестку и фиксацией результатов в соответствующем протоколе. Очевидно, что эксперту необходимо изучить всю документацию, связанную с утверждением Смет и сопоставить назначения установленных тарифов с размером ставки в рублях и периодом действия этих тарифов в рамках проведения судебной (процессуальной) экспертизы или внепроцессуального исследования.

Для подтверждения правильности выставления счетов по утверждённым тарифам с учетом установленного и согласованного с собственниками недвижимости уровня рентабельности эксперту необходимы расчетные документы управляющей компании - квитанции и персонифицированные данные по расчетам размера платы за жилое помещение, коммунальные услуги, содержание имущества общего пользования и иные услуги, документы о полученных денежных средствах от конкретных лиц в адрес управляющей компании. Все вопросы, адресованные эксперту для исследования, должны быть указаны в определении суда о назначении экспертизы или в договоре на проведение внепроцессуального исследования. В случае, если судебный спор ведется в отношении определенных собственников, относительно предъявленных им к оплате суммам на содержание имущества общего пользования, то целесообразно также рассмотреть и произвести проверку правильности начисления тарифов по исследуемому периоду в адрес других собственников коттеджного поселка, чье имущество соизмеримо 
по размерам площади и условиям расположения с имуществом исследуемых лиц. Также необходимо убедиться, что собственники недвижимости участвуют в эксплуатации имущества общего пользования и, следовательно, расходы на его содержание нести обязаны. Такое сопоставление позволит подтвердить или опровергнуть равнозначность и правильность применения тарифов и распределения сумм в адрес определенных лиц, произведения расчетов между собственниками и управляющей компанией.

Порядок проведения судебной экспертизы и внепроцессуального исследования в различных юридических процессах отличается процедурными нормами, содержащимися в процессуальном законодательстве. При этом, методика проведения исследования правильности установления и применения тарифов управляющей компании в отношении содержания имущества общего пользования будет одинакова. Итоговым этапом экспертизы является оформление результатов исследования в документальном виде: по результатам судебной (процессуальной) экспертизы должно быть составлено заключение эксперта, по результатам внепроцессуального исследования иной итоговый документ, например, акт внепроцессуального исследования.

В итоговом документе, (в заключении эксперта или в акте внепроцессуального исследования), эксперт или эксперты выражают свою мотивированную позицию, полученные результаты и выводы. По нашему мнению, выводы должны содержать четкие и однозначные формулировки, не позволяющие рассуждать о вероятности установленных фактов и обстоятельств. Помимо представления выводов, в итоговом документе описываются объекты и материалы исследования, перечень нормативных документов, иных значимых для исследования источников; примененные методы и приемы исследования; результаты исследования. В приложениях к итоговому документу могут содержаться иллюстративные материалы, копии исследуемых документов, которые имеют значение для целей экспертизы и упомянуты в тексте заключения.

\section{Выводы.}

Коттеджные поселки - любимый многими и довольно популярный вид недвижимости. Такое поселение совмещает в себе удобство городской инфраструктуры, ухоженные территории с природным ландшафтом и индивидуальные объекты строительства. Справедливо, что вопросы, связанные с наличием управляющей компании на такой территории и выполнением ею услуг по обслуживанию целевого объекта, формированию тарифов на оказанные услуги, сегодня актуальны. Разногласия между собственниками недвижимого имущества коттеджного поселка и управляющей компанией по управлению общим имуществом решаются в досудебном и судебном порядке. Интерес к данной теме и неоднозначность разрешения спорных ситуаций подтверждены различной судебной практикой. Проведение судебной (процессуальной) экспертизы или внепроцессуального исследования в области экономики и финансов позволяет объективно оценить справедливость применяемых и размер установленных управляющей компанией тарифов, проверить правильность начисления платы за услуги управляющей компании коттеджным поселком в адрес лиц, эксплуатирующих имущество общего пользования, установить факт наличия долга и определить его реальную сумму со стороны собственников имущества перед управляющей компанией.

Авторы в процессе исследования пришли к следующим выводам:

1) законодательно не определено понятие коттеджного поселка и перечня имущества, включаемого в общее имущество коттеджного поселка;

2) оказание услуг по управлению имуществом общего пользования в коттеджном поселке целесообразно отнести к лицензируемым видам деятельности, по аналогии с деятельностью по управлению многоквартирными домами;

3) с целью соблюдения прав собственников, справедливо будет законодательно закрепить обязательства по публикации отчетной информации о деятельности управляющей компании, что позволит пользователям имущества иметь дополнительный контроль за деятельностью и даст возможность получения важной финансовой информации о деятельности управляющей компании;

В статье описан порядок проведения судебной (процессуальной) экспертизы или внепроцессуального исследования в области экономики и финансов, где объектом исследования выступают примененные управляющей компанией тарифы, их уровень и начисление платы по данным тарифам лицам, осуществляющим эксплуатацию имущества общего пользования. В модели исследования авторами учтены требования российского законодательства по бухгалтерскому учету и налогообложению. 


\section{Библиографический список}

1. Информация Федеральной налоговой службы от 11 мая 2017 г. «Налоговая нагрузка по видам экономической деятельности, в процентах (актуализировано с учетом данных за 2016 г. в соответствии в пунктом 6 приказа ФНС России от 30 мая 2007 г. № MM-3-06/333@)» // СПС.Гарант // URL: https://www.garant.ru/ products/ipo/prime/doc/71575268/ (Дата обращения 22.11.2020).

2. Каменева E.A. «Формирование цен и тарифов на услуги управляющей организации в жилищнокоммунальном хозяйстве» // Ценообразование в ЖКХ. - 2012. - № 35(511). - с. 40-45.

3. Налоговый Кодекс Российской Федерации часть вторая (с изменениями на 9 ноября 2020 года), (редакция, действующая с 15 ноября 2020 года)

4. Определение Конституционного Суда РФ от 25.06.2019 N 1625-О «Об отказе в принятии к рассмотрению жалобы гражданина Спичака Олега Викторовича на нарушение его конституционных прав частью 3 статьи 30, частью 2 статьи 154 Жилищного кодекса Российской Федерации, статьей 210, пунктом 1 статьи 421 Гражданского кодекса Российской Федерации»

5. Письмо Минфина РФ от 03.07.2018 № 03-03-06/1/45756 11 июля 2018 «О внесении изменений в учетную политику для целей налога на прибыль».

6. Письмо Минфина РФ от 08.12.2017 № 03-03-06/1/81943 11 января 2018 «Об определении и учете прямых и косвенных расходов в целях налога на прибыль и изменении метода учета затрат».

7. Письмо Минфина России от 09.02.2016 № 03-03-06/1/6641 «Налоговый учет организаций - участников свободной экономической зоны»

8. План счетов бухгалтерского учета финансово-хозяйственной деятельности организаций, утвержденным Приказом Минфина РФ от 31.10.2000 N 94н (ред. от 08.11.2010)

9. Постановление Госстроя РФ от 27 сентября 2003 г. N 170 «Об утверждении Правил и норм технической эксплуатации жилищного фонда» вместе с утвержденными Правилами / CПС. Гарант. // URL: https://base. garant.ru/12132859 (Дата обращения 23.10.2020).

10. Постановление Конституционного Суда РФ от 10.11.2016 N 23-П «По делу о проверке конституционности положений абзаца второго пункта 1 статьи 2 Федерального закона «О государственной регистрации прав на недвижимое имущество и сделок с ним» в связи с жалобой гражданина Н.Н. Марасанова»

11. Постановление Правительства РФ от 04.04.2016 N 265 «О предельных значениях дохода, полученного от осуществления предпринимательской деятельности, для каждой категории субъектов малого и среднего предпринимательства»

12. Постановление Правительства РФ от 13.08.2006 N 491»Об утверждении Правил содержания общего имущества в многоквартирном доме и правил изменения размера платы за содержание жилого помещения в случае оказания услуг и выполнения работ по управлению, содержанию и ремонту общего имущества в многоквартирном доме ненадлежащего качества и (или) с перерывами, превышающими установленную продолжительность»

13. Постановление Правительства РФ от 6 февраля 2006 г. N 75 «О порядке проведения органом местного самоуправления открытого конкурса по отбору управляющей организации для управления многоквартирным домом» (с изменениями и дополнениями) / СПС. Гарант. // URL: https://base.garant.ru/12144905/ (Дата обращения 23.10.2020).

14. Приказ Минстроя России от 30.08.2017 N 1186/пр «Об утверждении Административного регламента по исполнению Министерством строительства и жилищно-коммунального хозяйства Российской Федерации государственной функции по осуществлению контроля за соблюдением органами исполнительной власти субъектов Российской Федерации, осуществляющими региональный государственный жилищный надзор, требований к лицензированию предпринимательской деятельности по управлению многоквартирными домами» (Зарегистрировано в Минюсте России 15.12.2017 N 49279)

15. Приказ Минфина РФ от 6 мая 1999 г. N 33н «Об утверждении Положения по бухгалтерскому учету «Расходы организации» ПБУ 10/99»

16. Приказ Минфина России от 06.10.2008 N 106н (ред. от 07.02.2020) «Об утверждении положений по бухгалтерскому учету» (вместе с «Положением по бухгалтерскому учету «Учетная политика организации» (ПБУ 1/2008)», «Положением по бухгалтерскому учету «Изменения оценочных значений» (ПБУ 21/2008)») (3арегистрировано в Минюсте России 27.10.2008 N 12522)

17. Приказ Минфина РФ от 6 июля 1999 г. N 43н «Об утверждении Положения по бухгалтерскому учету «Бухгалтерская отчетность организации» ПБУ 4/99» (с изменениями и дополнениями) 
18. Приложение № 3 к Приказу ФНС России от 30.05.07 № ММ-3-06/333 “Информация Федеральной налоговой службы от 23 мая 2019 г. «Среднеотраслевые показатели, характеризующие финансово-хозяйственную деятельность налогоплательщиков за 2018 год» // СПС Гарант / URL: https:/www.garant.ru/products/ipo/prime/ doc/72147454/ (Дата обращения 24.10.2020 г.)

19. См., например, Султанов Р. Некоторые спорные вопросы управления загородной недвижимостью: проблемы создания ТСЖ и их последствия // Жилищное право. 2017. N 3. С. 55-65.

20. См., например, Определение ВС РФ от 10 апреля 2019 г. № 303-ЭС19-3298, постановление Арбитражного суда Дальневосточного округа от 15 января 2019 г. № Ф03-5262/18

21. СП 42.13330.2016. Свод правил. Градостроительство. Планировка и застройка городских и сельских поселений. Актуализированная редакция СНиП 2.07.01-89*», (утв. Приказом Минстроя России от $30.12 .2016 \mathrm{~N}$ 1034/пр), М., 2016.

22. Федеральный закон от 06.12.2011 N 402-ФЗ (ред. от 26.07.2019) «О бухгалтерском учете» (с изм. и доп., вступ. в силу с 01.01.2020)

23. Федеральный закон от 24.07.2007 N 209-Ф3 (ред. от 27.10.2020) «О развитии малого и среднего предпринимательства в Российской Федерации»

24. Федеральный закон от 30.12.2008 N 307-ФЗ (ред. от 26.11.2019, с изм. от 01.04.2020) «Об аудиторской деятельности» 